\title{
Paulina Charko-Klekot
}

Uniwersytet Śląski w Katowicach

iD

ORCID https://orcid.org/0000-0002-1265-6934

Павел Руднев, Драма памяти.

Очерки истории российской драматургии. 1950-2010-е,

Новое литературное обозрение, Москва 2018

W ślad za Josifem Brodskim, Paweł Rudniew ${ }^{1}$ zwraca się do czytelników słowami: „[...] поэт там начинает, где предшественник кончил. Это как лестница; только начинаешь не с первой ступеньки, а с последней. И следующую сам себе сколачиваешь...”2, oddając tym samym główną myśl swojej publikacji - przekonanie o ciągłości procesu dramaturgicznego w Rosji. Własny punkt widzenia przedstawia już w pierwszym akapicie wstępu, wspominając o dwóch celach przyświecających mu podczas pisania: spojrzeniu

\footnotetext{
${ }^{1}$ Paweł Rudniew (ur. 1976) należy do czołówki współczesnych krytyków teatralnych oraz badaczy teatru i dramatu w Rosji. Jest doktorem historii sztuki, obecnie pracuje jako asystent rektora Szkoły-Studia MChAT w Moskwie, wykłada m.in. na Rosyjskim Uniwersytecie Sztuki Teatralnej (GITIS), jako ekspert i członek jury bierze udział w wielu festiwalach teatralnych i dramaturgicznych (z tych najbardziej znanych można wymienić takie festiwale jak np. „Евразия”, „Кульминация”, „Любимовка”, „Ремарка”). Ponadto tłumaczy utwory dramaturgiczne z języka angielskiego (np. Marka Ravenhilla czy Martina McDonagha), aktywnie publikuje teksty krytycznoliterackie i naukowe o współczesnym życiu teatralnym w Rosji i na świecie. Książka Драма памяти. Очерки истории российской драматургии. 1950-2010-е jest jego drugą monografią — pierwszą była wydana w 2003 roku rozprawa Театральные взгляды Василия Розанова.

${ }^{2}$ И. Бродский, Мрамор, суt. za: П. Руднев, Драма памяти. Очерки истории российской драматургии. 1950-2010-е, Новое литературное обозрение, Москва 2018, s. 9.
} 
na rozwój sowieckiej dramaturgii z perspektywy człowieka żyjącego w innej epoce oraz właśnie popularyzacji idei nieprzerwanego rozwoju rosyjskiej dramaturgii ${ }^{3}$. Maria Riewiakina, dyrektor festiwalu teatralnego „Złota Maska”, przy współpracy którego recenzowana monografia powstała, na premierze książki podkreślała znaczenie pamięci w opublikowanej pozycji: „Эта книга очень важна не только как драма памяти, но и как историческая память о том,

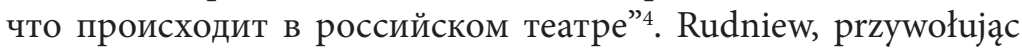
sylwetki i twórczość dramatopisarzy od lat 50. XX wieku po pierwsze dziesięciolecie XXI wieku, nie tylko podejmuje próbę ukazania linearności historii dramaturgii rosyjskiej, ale również przywraca pamięć o niektórych autorach czy zjawiskach teatralnych, sprzeciwiając się wybiórczemu odczytywaniu przeszłości, „wykreślaniu” niewygodnych w danym momencie wydarzeń czy osób. Tym samym polemizuje z założeniami literatury i sztuki postmodernistycznej, która odcinając się od dziedzictwa socrealizmu, czyni go przedmiotem prześmiewczej gry, ironicznego, demitologizującego namysłu nad jej symbolami, stereotypami ideami i ideałami.

Zmęczony dyskursem opartym na opozycjach sowieckie-antysowieckie/postsowieckie, badacz postanowił przedstawić inne spojrzenie na historię dramatu - w miejsce odżegnywania się od sztuk napisanych w Związku Radzieckim Rudniew postuluje odszukanie w nich korzeni współczesnych procesów teatralnych. Podczas premiery książki literaturoznawca mówił, że kierowała nim potrzeba połączenia twórczości różnych pokoleń dramaturgów, zniwelowania przepaści, która zbytnimi uproszczeniami doprowadziła do bardzo jednoznacznych (o)sądów. Rudniew dostrzega (i krytykuje) tendencję do zbyt kategorycznego odbioru zarówno sowieckich autorów, jak i młodych adeptów tej sztuki - czytelnicy albo ich kochają, albo nimi pogardzają, oceniając ich pisarstwo w ramach odrębnych procesów, co szkodzi zarówno

\footnotetext{
${ }^{3}$ Tamże, s. 5.

${ }^{4}$ А. Павловна, Павел Руднев: „Театр - территория памяти”, http:// teatron-journal.ru/2018/04/02/out_genre-books-prez-rudnev/ (20.11.2019).
} 
jednym, jak i drugim ${ }^{5}$. Kontekst historyczno-polityczny wpłynął na postrzeganie literatury i sztuki ZSRR jako w pewien sposób gorszej, gdyż naznaczonej ideologią, od której należy się odciąć. Rudniew polemizuje $\mathrm{z}$ takim podejściem, twierdząc, że pozbawiając współczesną dramaturgię związków z dramaturgią sowiecką, społeczeństwo „wymazuje” pamięć o swojej tożsamości - tożsamości, która mogła wyrastać z opozycji wobec tamtej twórczości albo z niej czerpać, ale nigdy nie powstawała w całkowitym oderwaniu od przeszłości.

Książka Rudniewa z pewnością wpisuje się w dynamicznie rozwijające się studia nad pamięcią (memory studies), będące wielodyscyplinarnym polem badawczym, interesującym historyków, socjologów, antropologów, literaturoznawców, kulturoznawców i innych. Paweł Rudniew temat pamięci traktuje jako pewnego rodzaju lejtmotyw powracający $\mathrm{w}$ analizie twórczości większości omawianych przez niego autorów:

$[\ldots]$ театр есть территория памяти, [...] театр работает со временем, пониманием времени, всегда говорит о времени. Театр говорит о прошлом в сегодняшнем процессе, запускает прошлое в сегодня. Мне кажется, что это очень существенная тема. И тема России, которая всегда движется скачками - не эволюционно, а революционно. Каждый новый мощный правитель зачеркивал прошлое, а если прошлое зачеркивается, то память оказывает твоим персональным заветом, память нужно присвоить. Эта тема, мне кажется, звучит везде $[\ldots]^{6}$.

Spojrzenie w kierunku sowieckiej dramaturgii zmusza współczesnych czytelników do rewizji przeszłości z wykorzystaniem kategorii pamięci kulturowej, rozumianej przez Jana Assmanna jako postawa zbiorowości w odniesieniu do minionej rzeczywistości ${ }^{7}$. Adam Rajewski w rozważaniach nad teorią pamięci Assmanna pisze, że pamięć kulturowa jest „uaktualniana za pomocą instrumentów społeczno-kulturowych wypracowanych przez daną

\footnotetext{
5 Tamże.

${ }^{6}$ Tamże.

${ }^{7}$ A. Rajewski, Rozważania na temat Assmannowskiej teorii pamięci, „Rocznik Antropologii Historii” 2013, R. III, nr 1 (4), s. 189.
} 
grupę"8 i wydaje się, że w tej możliwości modyfikowania pamięci kulturowej Rudniew widzi szansę na rozliczenie się z przeszłością, dekanonizację repertuaru, wyzwolenie $\mathrm{z}$ dotychczas przyjętego sposobu odbioru sztuk radzieckich ${ }^{9}$. Autor przekonuje, że zdjęcie ograniczeń ideologicznych pozwoli na szersze odczytanie sztuk tamtego okresu, a także na poszukiwanie odpowiedzi na pytania o to, kim był homo sovieticus, często świetnie sportretowany przez ówczesnych dramaturgów. A pytania o człowieka sowieckiego prowadzą w prostej linii do pytań o istotę człowieka współczesnego, co Irina Prochorowa komentuje następująco:

Книга Павла Руднева - это попытка посмотреть традицию российского театра, начиная с „Оттепели”. Выяснить, как традиция советская так или иначе неожиданным образом преломляется, продолжается в нынешнем театре. Лейтмотив книги Павла Руднева в том, что тотальное изменение - это иллюзия. Нам кажется, что катаклизмы всегда отменяют предыдущую традицию, но выясняется, что нет. Книга пытается исследовать, что наследуется, как эта матрица воспроизводится. Это замечательная точка отсчета - откуда мы и куда придем ${ }^{10}$.

Jeśli przyjąć, że pamięć jest sposobem konstytuowania przez ludzi swojej przeszłości ${ }^{11}$, niezwykle ważne staje się zrozumienie, że zaprzeczając ciągłości procesów dramaturgicznych w Rosji trudno o zachowanie wiarygodności współczesnej sztuki. Tym bardziej że przykładów na interferencje jest mnóstwo, co w swojej książce pokazuje Rudniew. Jednym z takich wspólnych dla wszystkich prezentowanych przez niego pokoleń dramatopisarzy tematów jest religia. Badacz uważa, że kwestie wiary podejmowali zarówno radzieccy, jak i współcześni dramaturdzy. W Związku Radzieckim autorzy usiłowali znaleźć alternatywę dla zakazanego chrześcijaństwa: „[...] розовская тема детства - это для меня абсолютная

\footnotetext{
${ }^{8}$ Tamże.

${ }^{9}$ П. Руднев, Драма памяти..., s. 6.

${ }^{10}$ А. Павловна, Павел Руднев: „Театр - территория памяти”...

${ }^{11}$ Ю.А. Сафронова, Третья волна mетоry studies: Двадияать три года против шерсти, „Политическая наука” 2018, nr 3, s. 16-17.
} 
замена христианских постулатов" - pisze Rudniew ${ }^{12}$. Z kolei mówiąc o XXI wieku, wystarczy przywołać chociażby Iwana Wyrypajewa, w którego sztukach wyraźnie wybrzmiewają religijne, duchowe kwestie.

Na stronicach swojej książki Rudniew próbuje pokazać w jaki sposób duchowe dziedzictwo „wielkiej czwórki” — jak nazywa Wiktora Rozowa, Aleksieja Arbuzowa, Aleksandra Wołodina i Aleksandra Wampiłowa - poprzez twórczość Ludmiły Pietruszewskiej czy Władimira Sorokina znalazło odbicie w pisarstwie tych, którzy dopiero wkraczają na deski teatrów - Jarosławy Pulinowicz czy Iriny Waśkowskiej. Podkreśla właściwą dla wszystkich pokoleń potrzebę poruszania ważnych w danym okresie zagadnień społecznych czy politycznych, reagowania na aktualne problemy oraz umiejętność celnego portretowania różnych środowisk ${ }^{13}$. Rudniew akcentuje związki współczesnego dramatu i teatru dokumentalnego z dramatem produkcyjnym popularnym w latach 70. - pytania, zadawane przez autorów „produkcyjniaków” o sposoby oddziaływania teatru na widza i poszukiwania tychże, powracają na początku XXI wieku na przykład w sztukach-verbatim ${ }^{14}$.

Podróż po radzieckiej i rosyjskiej dramaturgii Rudniew zaczyna od wspomnianego już Rozowa, którego sztuka Wiecznie żywi (Beчно живыц, 1943), dając zupełnie odmienny obraz Wielkiej Wojny Ojczyźnianej, rozpoczęła nową erę w teatrze sowieckim ${ }^{15}$. W kolejnych rozdziałach (a cała książka liczy ich 27 - każdy poświęcony jednemu twórcy lub zjawisku teatralnemu) przybliża dorobek Arbuzowa, Wołodina i Wampiłowa. Przypomina sztuki Ałły Sokołowej, traktując jej dramaturgię jako swego rodzaju most pomiędzy dojrzałą dramaturgią sowiecką a dramaturgią okresu pieriestrojki, reprezentowaną w książce przez Ludmiłę Pietruszewską, Wie-

${ }^{12}$ А. Павловна, Павел Руднев: „Театр - территория памяти”...

13 Zob. A. Демахин, В современном театре нет героя. Но есть ли он в окружающей жизни? Память драмы, „Учительская газета” 2018, nr 25, http://www.ug.ru/archive/74987 (20.11.2019).

${ }^{14}$ Zob. П. Руднев, Драма памяти..., s. 114-117, 473-475.

${ }^{15}$ Tamże, s. 10. 
niedikta Jerofiejewa i Władimira Sorokina. Palmę pierwszeństwa przyznaje Rudniew Pietruszewskiej, którą nazywa jednym z większych reformatorów rosyjskiego dramatu: „Она закрывает советскую эпоху и начинает новую. Без ее реформ в области драматургического письма и языка не появилась бы новейшая пьеса 1990-2000-ых годов, которая выходит из корпуса ее текстов, из ее эстетики непосредственно"16. Badacz usiłuje zrehabilitować dramaturgię produkcyjną, wskazując na jej osiągnięcia w zakresie formy i kompozycji (i podkreślając wspomniany wpływ na dzisiejszą sztukę dokumentalną). Sięga również do innego, popularnego w latach 70. i 80. zjawiska, jakim była tzw. усадебная драматургия, podejmująca znaną literaturze od czasów Iwana Turgieniewa problematykę gniazda szlacheckiego jako nosiciela spuścizny duchowej i intelektualnej. Omówienie dramaturgii XX wieku Rudniew rozpoczyna „teoretycznym” rozdziałem, w którym wymienia główne tematy poruszane przez twórców „nowego dramatu” (np. globalizacja, poszukiwania tożsamościowe, kryzys kultury, przemoc jako forma komunikacji), by w kolejnych częściach książki omówić poszczególne zagadnienia na podstawie twórczości konkretnych autorów. Przedstawia w jaki sposób bohaterowie z marginesu, wprowadzeni do dramaturgii przez Pietruszewską, ulegają przeobrażeniom w sztukach Nikołaja Kolady, jego uczniów (Wasilija Sigariewa, Jarosławy Pulinowicz) czy również pochodzących z Jekaterynburga, ale nie związanych ze „szkołą uralską” braci Olega i Władimira Priesniakowów. Najmłodsze pokolenie dramatopisarzy reprezentują Paweł Priażko, Irina Waśkowska i wspomniana Pulinowicz. Oddzielne rozdziały Rudniew poświęca na rozważania o dramacie dokumentalnym oraz o ewolucji bohatera we współczesnej dramaturgii.

Recenzowana książka jest ważną publikacją na rosyjskim rynku wydawniczym, z dużym potencjałem podbicia rynków zagranicznych. Podczas premiery publikacji Rudniew podkreślał brak podobnych pozycji: „Желание написать эту книгу исходило из того, что о советской драматургической классике почти нет изданий. Нет такого рода работ, которые могли бы провести

\footnotetext{
${ }^{16}$ Tamże, s. 175.
} 
какую-то линию эволюции драматургии от советского периода до наших дней"17. I rzeczywiście, jeśli chodzi o tak obszerną monografię, podejmującą próbę przedstawienia ponad pół wie$\mathrm{ku}$ rosyjskiej dramaturgii, jest to z pewnością pozycja pionierska. $\mathrm{Z}$ istniejących opracowań wspomnieć można podręczniki Margarity Gromowej, do korzystania z których w wywiadach przyznaje się sam Rudniew ${ }^{18}$ (Русская драматургия конца XX - начала ХХІ века. Учебное пособие, 2009; Русская современная драматургия. Учебное пособие, 2013) czy Swietłany Gonczarowej-Grabowskiej (Поэтика современной русской драмь (конеи, XX начало ХХІ века), 2003; Комедия в русской драматургии кониа $X X$ - начала XXI века, 2008). W teatralnej serii wydawnictwa Новое литературное обозрение, w ramach której ukazała się książka Pawła Rudniewa, inne pozycje podejmujące zagadnienia współczesnego dramatu, jednak nie w tak obszernym wymiarze, to m.in. Пербормансы насилия. Литературные и театральные эксперименты „новой драмь” (2012) Marka Lipowieckiego i Birgit Beumers czy Театр эпохи перемен в Польше, Венгрии и России 1990-e-2010-е годы (2014) Natalii Jakubowej. Obie pozycje skupiają się na najnowszej dramaturgii - Lipowiecki i Beumers podejmują problem przemocy (w różnych jej przejawach) jako sposobu komunikacji w społeczeństwie, z kolei Jakubowa porównuje rosyjskie przemiany teatralne przełomu wieków, konfrontując je z sytuacją na Węgrzech i w Polsce. Z pewnością więc książka Rudniewa jest pracą, która wypełnia lukę na rynku wydawniczym. Nie ulega wątpliwości, że okaże się pomocna osobom zawodowo zajmującym się dramatem i teatrem rosyjskim, jednak ze względu na swobodny styl wypowiedzi, prosty, ale ciekawy język, bliski literaturze popularnonaukowej, może zaciekawić nie tylko profesjonalistów. Tym bardziej że autor niejednokrotnie podkreślał, iż jego monografia nie jest podręcznikiem - nie ma w niej not biograficznych, pominięto inscenizacje teatralne omawianych sztuk, brakuje przypisów czy odwołań do innych prac krytycznych (książ-

\footnotetext{
${ }^{17}$ А. Павловна, Павел Руднев: „Театр - территория памяти”...

${ }^{18}$ Tamże.
} 
ka nie została opatrzona bibliografią), a i wybór autorów jest jak najbardziej subiektywny. Takie podejście Rudniew usprawiedliwia następująco: „Это сделано сознательно с технологическими целями: автор хотел бы сосредоточиться только на самом предмете - анализе драмы через медленное чтение текста наедине с автором"19. W niczym nie umniejsza to wielkości książki, która, z jednej strony, stanowi obszerne źródło wiedzy o dramacie rosyjskim na przestrzeni kilku dekad, z drugiej zaś polemizuje ze stereotypowym przekonaniem, że od czasów Wampiłowa w dramaturgii rosyjskiej nie pojawiła się żadna znacząca postać. Udowadniając nieprawdziwość takich kontestacji, Rudniew przytacza kilkanaście nazwisk późniejszych pisarzy obdarzonych ogromnych talentem, zarówno jeśli chodzi o dobór tematów, jak i język utworów. Z powodzeniem potwierdza postawioną przez siebie tezę o wzajemnym oddziaływaniu i dialogu międzypokoleniowym. Pokazuje, że niezależnie od czasów, w jakich przyszło żyć autorom, jednym z ich głównych celów jest diagnoza otaczającej rzeczywistości, zmuszanie widzów i czytelników do rozważań na temat odwiecznych pytań o sens egzystencji.

${ }^{19}$ П. Руднев, Драма памяти..., s. 9. 